\title{
Myxomycetes in Brazilian mangroves: species associated with Avicennia nitida, Laguncularia racemosa and Rhizophora mangle
}

\author{
Laise de Holanda Cavalcanti, Glauciane Damasceno, Antonia Aurelice Aurélio Costa and \\ Andrea Carla Caldas Bezerra
}

\begin{abstract}
Background: Mangroves are distributed among tropical and subtropical coastlines of all oceans, and associated macroflora and macrofauna are generally well studied. However, information on mangrove-associated microbiota is still scarce. To help fill this gap in knowledge, we conducted research on the occurrence of Myxomycetes in the southern coast of Pernambuco state, northeastern Brazil. In the Rio Formoso estuary, we examined adult Rhizophora mangle (Rm), Laguncularia racemosa (Lr) and Avicennia nitida (An), collecting samples of live trunk bark (Bk), twigs from aerial litter (Tg), and aerial leaf litter (Lf) for moist chamber culture $(n=600)$.

Results: The following species were identified: Arcyria cinerea (Rm/Tg); A. pomiformis (Rm;Lr/Bk); Collaria arcyrionema (Rm/B); Clastoderma debaryanum (Lr/Bk; Rm/Tg); Cribraria violacea (Rm/Bk;Tg); Physarum auriscalpium (Rm/Tg); P. tenerum (Rm/Bk); Stemonitis fusca ( $\mathrm{Lr} / \mathrm{Tg})$; S. herbatica (Rm/Lf); S. virginiensis $(\mathrm{Rm} / \mathrm{Tg})$ and Stemonaria irregularis (An/Lf). The percentage of positive cultures was very low (24\%), with $\mathrm{Rm}$ as the predominant substrate with eight species and $\mathrm{Tg}$ as the predominant microhabitat. The majority of species are rare (60 \%) and Physarum auriscalpium was the only species frequently registered. The taxonomic diversity indices ranged from 1.00 (Lf;Bk) to 1.20 (Tg).

Conclusions: There was no similarity in the composition of myxobiota found on the substrates and microhabitats analyzed. Only S. irregularis was found in mangroves that inhabit areas of higher salinity. Physarum tenerum is reported here for the first time in the mangrove environment.
\end{abstract}

Keywords: Aerial litter, Black mangrove, Microhabitats, Myxobiota, New record, Red mangrove

\section{Introduction}

The mangrove ecosystem represents a transition between land and marine environments in which river water meets seawater, and is characteristic of coastal tropical and subtropical regions (Schaeffer-Novelli 1995; Krug et al. 2007). Mangrove habitats include a total area of $181,000 \mathrm{~km}^{2}$ spanning 112 countries and territories, and dominate approximately a quarter of the world's coasts (Sridhar 2004). Brazil has one of the largest expanses of mangroves in the world $(6800 \mathrm{~km})$, extending

\footnotetext{
* Correspondence: Ihcandrade2@gmail.com

Laboratório de Myxomycetes, Departamento de Botânica, Centro de Biociências, Universidade Federal de Pernambuco, Av. Prof Moraes Rego sn, 50740-550 Recife, PE, Brazil
}

from the northern region in Amapá state to the southern state of Santa Catarina (Krug et al. 2007).

Mangrove environmental conditions include provision of shelter and food for mammals, birds, reptiles, fishes, mollusks, insects and various groups of microorganisms, all of which may exist in the system as residents or as visitors, either regularly or opportunistically (Leitão 1995; Schaeffer-Novelli 1995). The phanerogamic flora of this restrictive environment consists of a few families and genera whose species, rooted in the substratum, have morphological, physiological and ecological adaptations that allow them to thrive under conditions of high salinity, extreme tides, strong winds, high temperatures and anaerobic soils (Schaeffer-Novelli 1995; Kathiresan 
and Bingham 2001). There is a rich diversity of epiphytes (plants and microorganisms), most of them not exclusive to the mangrove ecosystem (Vannucci 2001).

Brazilian mangrove myxomycetes were first registered by Bezerra et al. (1999); Cavalcanti et al. (2000), in which the authors identified five species associated with Rhizophora mangle L., one with Stereum hirsutum (Willd.:Fr.) S. Gray and 11 species with Laguncularia racemosa (L.) C.F. Gaertn., in the states of Amapá, Pará, Pernambuco and Sergipe. Trierveiler-Pereira et al. (2008) collected six specimens on trunk bark of Avicennia schaueriana Stapf. \& Leechm ex Moldenke in Santa Catarina state, in the southern region of Brazil, which were later identified as Stemonitis fusca Roth, S. splendens Rostaf. and Physarum pezizoideum (Jungh) Pav. \& Lag.

Studies initiated in 2007 in the Rio Formoso municipality on the southern coast of Pernambuco resulted in the registration of 23 species and 14 genera associated with trees and shrubs typical of mangrove, including some not previously recorded in the Neotropics or in the mangrove environment (Damasceno et al. 2011, 2009; Cavalcanti et al. 2014). Continuing these studies, we present new records of myxomycetes on Avicennia nitida Jacq., L. racemosa and $R$. mangle microhabitats, thereby contributing to the increase in knowledge of myxomycetes present in ecosystems associated with the Atlantic Forest, particularly corticolous species and those found in aerial litter.

\section{Materials and methods}

The Rio Formoso estuary is roughly $12 \mathrm{~km}$ long, formed by four contributing rivers: Formoso, dos Passos, Lemenho and Ariquindá. It is located in the municipality of Rio Formoso $\left(8^{\circ} 39^{\prime}-8^{\circ} 42^{\prime} \mathrm{S}\right.$ and $35^{\circ} 10^{\prime}-35^{\circ} 05^{\prime}$ W), $90 \mathrm{~km}$ south of Recife, the capital of Pernambuco state, and about $4 \mathrm{~km}$ north of Tamandaré Bay (Fig. 1). The banks of the estuary are almost entirely covered by typical mangrove vegetation, including $A$. nitida, $A$. schaueriana, Conocarpus erectus L., L. racemosa and $R$. mangle (Botelho et al. 2000).

Avicennia nitida, known as black mangrove, siriuba or canoé mangrove, is tree or shrub-sized with smooth trunk bark that when scraped, presents a yellowish color. The species reaches an average height of $10 \mathrm{~m}$ with an average trunk diameter of $20 \mathrm{~cm}$, and a sub-aerial root system with pneumatophore. This species occupies areas of high salinity, especially in river mouths (Schuler et al. 2000; Maia et al. 2005).

Laguncularia racemosa, popularly known as white mangrove, manso mangrove or tinteiro, has intermediate salt tolerance and commonly presents as a small tree with a trunk diameter of about $30 \mathrm{~cm}$, with potential to reach $12 \mathrm{~m}$ tall; its leaves are characterized by a red petiole with two glands at the top and a root system similar to that of Avicennia, which it is sometimes found near (Schuler et al. 2000; Maia et al. 2005).

Rhizophora mangle, commonly known as the red mangrove, is characterized by having aerial roots that extend from the trunk to the muddy ground, allowing greater support. It has smooth and clear stem bark that, when shaved, presents a reddish color. This species can reach a height of $19 \mathrm{~m}$, with an average trunk diameter of about $30 \mathrm{~cm}$. It grows best at low and intermediate salinity in the estuarine zone, in areas with lower than 50 parts salt per 1000 parts water (Schuler et al. 2000; Maia et al. 2005).

Excursions to mangroves of the Rio Formoso and Rio dos Passos were carried out over a period of 12 consecutive months, from the beginning of rainy season through the end of the dry season. Sample collections and field observations were carried out at seven sampling points established between $100 \mathrm{~m}$ and $1 \mathrm{~km}$ apart; the total sampling area spanned $6 \mathrm{~km}$. In addition to direct observation of adult A. nitida, $L$. racemosa and $R$. mangle, aerial litter samples were collected by separating leaves (Lf) and twigs (Tg), and live tree bark (Bk). A total of 200 moist chamber cultures were established for each mangrove species (Novozhilov et al. 2000). Cultures $(n=600)$ were kept in ambient light and temperature conditions, and checked weekly for 3 months for presence of plasmodium or sporophores.

Species identification was performed using Lister (1925); Martin and Alexopoulos (1969); Farr (1976); Lado and Pando (1997); Poulain et al. (2011). Representative specimens of the material were deposited in the UFP herbarium (Thiers 2014).

We calculated (1) the percentage of positive cultures; (2) the taxonomic diversity index for each substrate and microhabitat type; (3) the abundance and frequency of species per microhabitat and (4) community coefficients for the assemblages of myxomycetes recorded in A. nitida, $L$. racemosa and $R$. mangle (Schnittler and Stephenson 2000; Novozhilov et al. 2006).

\section{Results}

Only $24 \%$ of cultures were positive (plasmodia or sporophores), yielding a total of 24 specimens, most (65\%) sporulated on aerial litter twigs, followed by live tree trunk bark (26\%), and rarely in aerial leaf litter (Table 1$)$. A total of 11 species, representing seven genera and five families, and all orders of Stemonitomycetidae and Myxogastromycetidae subclasses were found in Avicennia nitida, Laguncularia racemosa and Rizophora mangle microhabitats. The Clastoderma (Clastodermataceae), Cribraria (Cribrariaceae), Collaria and Stemonaria (Stemonitaceae) genera were represented by only one species each. Trichiaceae (Arcyria) and Physaraceae 


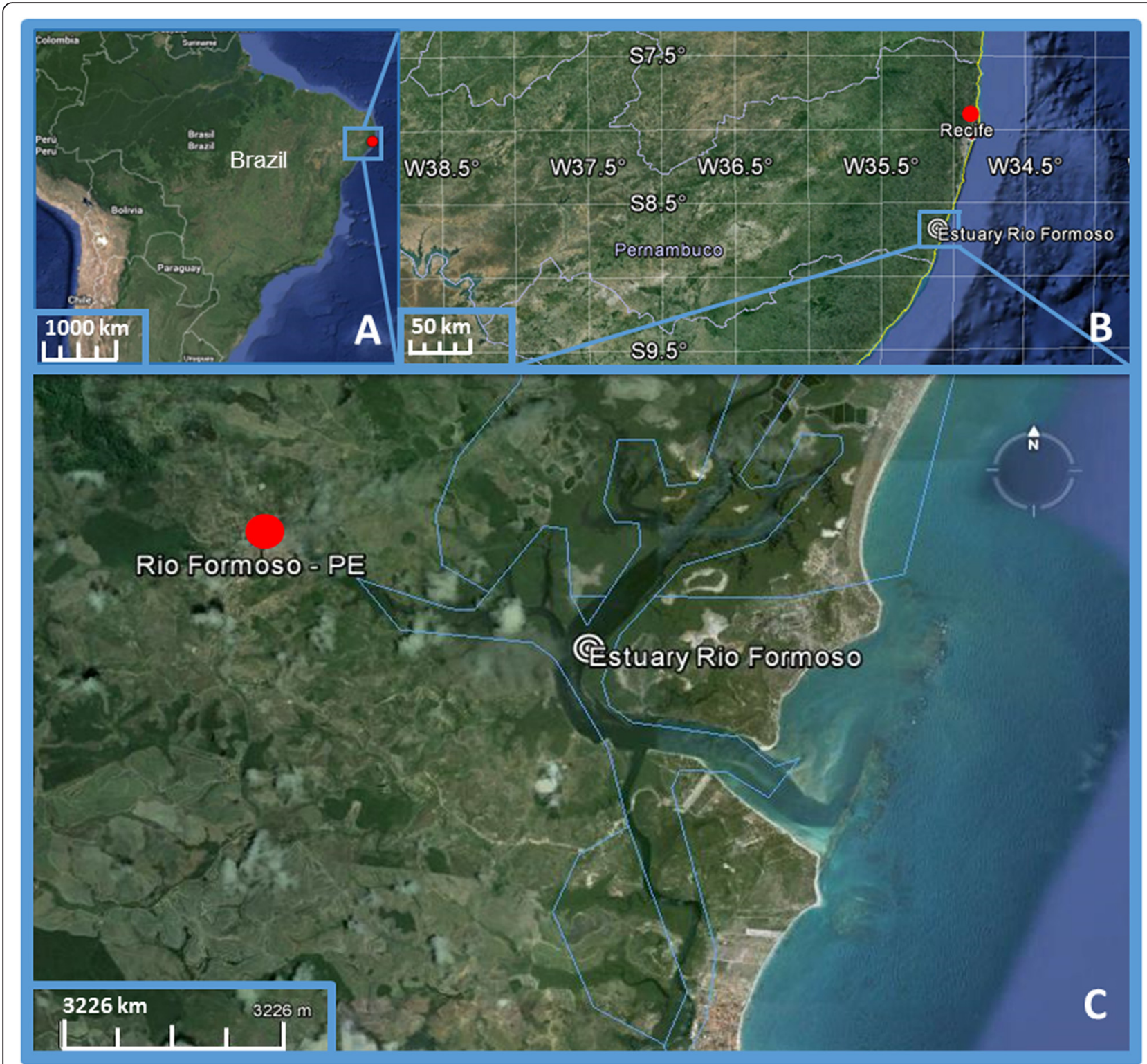

Fig. 1 Geographical location of the study area in Brazil (a), Pernambuco state (b), Rio Formoso city (c)

(Physarum) were represented by one genus and two species each. Stemonitaceae (Collaria, Stemonitis, Stemonaria) was the richest group, with three genera and four species (Table 1).

\section{Arcyria cinerea (Bull.) Pers}

Rare; found in aerial leaf litter of R. mangle (Table 1).

Cosmopolitan species (Martin and Alexopoulos 1969). Widely distributed in Brazil can sporulate in a variety of environments and substrates, particularly fallen logs (Cavalcanti 2014a).

Arcyria cinerea was the first species of the group reported to occur in the mangrove environment, sporulating on dead trunk of $R$. mangle in Hawaii (Kohlmeyer 1969).
In Brazil, this species is reported to occur only in Rio Formoso mangroves, noted by Cavalcanti et al. (2014) as being among the uncommon species of myxobiota of Conocarpus erectus, sporulating on leaf and twig components of the aerial litter.

\section{Arcyria pomiformis (Leers) Rostaf.}

Infrequent; found on bark of living trunk of $L$. racemosa (Table 1).

Reported to occur in seven states of Brazil, from the Northeast to the Southeast and South (Cavalcanti 2014a).

Arcyria pomiformis may in some cases be confused with A. cinerea, however the two differ in color, size, 
Table 1 Taxonomic diversity, abundance and frequency of occurrence of myxomycetes in the microhabitats offered by Avicennia nitida Jacq., Laguncularia racemosa (L.) C.F. Gaertn. and Rizophora mangle L. Rio Formoso municipality, Pernambuco, Brazil

\begin{tabular}{|c|c|c|c|c|}
\hline \multirow[t]{2}{*}{ Taxon } & \multicolumn{3}{|c|}{ Microhabitat/Abundance ( $\mathrm{n}^{0}$ specimens) } & \multirow[t]{2}{*}{ Frequency } \\
\hline & Lf & $\operatorname{Tg}$ & Bk & \\
\hline \multicolumn{5}{|l|}{ Clastodermataceae } \\
\hline Clastoderma debaryanum & 0 & $3(\mathrm{Rm})$ & $2(L r)$ & Infrequent \\
\hline \multicolumn{5}{|l|}{ Cribrariaceae } \\
\hline Cribraria violacea & 0 & $3(\mathrm{Rm})$ & $1(\mathrm{Rm})$ & Infrequent \\
\hline \multicolumn{5}{|l|}{ Physaraceae } \\
\hline Physarum auriscalpium & 0 & $6(\mathrm{Rm})$ & 0 & Frequent \\
\hline Physarum tenerum & 0 & 0 & $1(\mathrm{Rm})$ & Rare \\
\hline \multicolumn{5}{|l|}{ Stemonitaceae } \\
\hline Collaria arcyrionema & 0 & 0 & $1(\mathrm{Rm})$ & Rare \\
\hline Stemonaria irregularis & $1(A n)$ & 0 & 0 & Rare \\
\hline Stemonitis fusca & 0 & $1(L r)$ & 0 & Rare \\
\hline Stemonitis herbatica & $1(\mathrm{Rm})$ & 0 & 0 & Rare \\
\hline Stemonitis virginiensis & 0 & $1(\mathrm{Rm})$ & 0 & Rare \\
\hline \multicolumn{5}{|l|}{ Trichiaceae } \\
\hline Arcyria cinerea & 0 & $1(\mathrm{Rm})$ & 0 & Rare \\
\hline Arcyria pomiformis & 0 & 0 & $2(L r)$ & Infrequent \\
\hline Abundance & 2 & 15 & 6 & \\
\hline$D_{\operatorname{tax}}$ & 1,00 & 1,20 & 1,00 & \\
\hline
\end{tabular}

$L f$ leaves of aerial litter, $T g$ twigs of aerial litter, $B k$ bark from living trees, Frequency very frequent $>10$; frequent $>5-10$; infrequent $>1-5$; rare $\leq 1, D_{\text {tax }}$ taxonomic diversity

and structure of the sporocarp and capillitium, and in the diameter and staining of cysts present in pedicels (Farr 1962).

This species was first mentioned to the mangrove environment by Cavalcanti et al. (2000), in which the authors obtained culture using moist chambers fitted with $L$. racemosa living trunk bark; this is the second report of $A$. pomiformis in the mangrove environment.

\section{Clastoderma debaryanum Blytt}

Infrequent; found in aerial leaf litter of $R$. mangle and on L. racemosa living trunk bark (Table 1).

Cosmopolitan species (Martin and Alexopoulos 1969). Found in various ecosystems in Brazil, reported in the states of Bahia, Paraíba, Pernambuco, Piauí, Rio Grande do Norte, Santa Catarina and São Paulo (Cavalcanti 2014b).

Clastoderma debaryanum was first reported to occur in mangroves by Cavalcanti et al. (2014) based on specimens obtained from Rio Formoso, Pernambuco state, sporulated on C. erectus.

Collaria arcyrionema (Rostaf.) Nann.-Bremek. ex Lado Rare; found on R. mangle live trunk bark (Table 1).
Cosmopolitan species (Martin and Alexopoulos 1969). Widely distributed in Brazil can sporulate in a variety of environments and substrates (Cavalcanti 2014a).

Collaria arcyrionema was first recorded in mangrove environment on the bark of live $L$. racemosa trunk in Pernambuco state (Cavalcanti et al. 2000).

\section{Cribraria violacea Rex}

Infrequent; found on $R$. mangle live trunk bark and twigs from aerial litter (Table 1).

Cosmopolitan species (Martin and Alexopoulos 1969). Reported in eight of the nine northeastern states, São Paulo state, in the Southeast, and Santa Catarina state, in the South (Cavalcanti 2014c).

Frequently found on decaying wood, moss and bark of live or dead trees, C. violacea was first recorded in mangrove environment in aerial litter and on the bark of live $R$. mangle trunk in Maranhão state (Agra et al. 2015).

The specimens obtained were developed in moist chambers on bark and twigs of live R. mangle (Table 1), and it was observed that sporocarps originating from the same plasmodium presented varying sizes, as was also reported by Farr (1976). 


\section{Physarum auriscalpium Cooke}

Frequent; found on $R$. mangle twigs in aerial litter (Table 1).

Few records for Brazil, reported only in Pernambuco, Rio de Janeiro and São Paulo states (Cavalcanti 2014d).

Physarum auriscalpium was reported for the first time in mangrove environment by Cavalcanti et al. (2014), occurring frequently on the bark of live C. erectus trunks.

\section{Physarum tenerum Rex}

Rare; found on live R. mangle trunk (Table 1).

Cosmopolitan species (Martin and Alexopoulos 1969). Reported to occur in only seven Brazilian states, but present in almost all regions of the country, from the Amazon to Rio Grande do Sul (Cavalcanti 2014d). The single specimen obtained showed few sporocarps with all the characteristics typical of the species, with the exception of the total height $(0.8 \mathrm{~mm})$ and the diameter of the sporotheca $(0.2 \mathrm{~mm})$. This is the first record of the species in a mangrove environment.

\section{Stemonaria irregularis (Rex) Nann.-Bremek.}

Rare; found in aerial leaf litter of $A$. nitida (Table 1).

In Brazil, S. irregularis has been reported only in the Northeast, collected on dead trunks in tropical evergreen forest in the interior of Ceará state, and in the coastal-forest zone of Pernambuco (Cavalcanti 2014e). This species was reported for the first time in mangroves by Damasceno et al. (2011), sporulating in $A$. nitida aerial litter, and in $C$. erectus live trunk bark and aerial litter.

\section{Stemonitis fusca Roth.}

Rare; found on L. racemosa aerial litter twigs (Table 1).

Cosmopolitan species (Martin and Alexopoulos 1969). Very common in various ecosystems, S. fusca is reported to occur in over half of the Brazilian states (61\%), including the Amazon rainforest, Caatinga and Atlantic Forest environments (Cavalcanti 2014e).

This species was first reported in mangroves by Trierveiler-Pereira et al. (2008), collected on Avicennia schaueriana bark in Santa Catarina. In Pernambuco, it is frequently found in C. erectus ground litter and aerial leaf litter, and rarely in L. racemosa aerial leaf litter (Damasceno et al. 2011; Cavalcanti et al. 2014).

\section{Stemonitis herbatica Peck}

Rare; found in $R$. mangle aerial leaf litter (Table 1).

Often dwells on herbaceous plants, and less commonly on decaying wood (Martin and Alexopoulos 1969). Recorded in Brazil in one state in the North, five in the Northeast, two in the Southeast and one in the South, according to Cavalcanti (2014e).
Stemonitis herbatica was recorded for the first time in the mangrove environment by Damasceno et al. (2011), sporulating on aerial leaf litter of $C$. erectus and $R$. mangle.

\section{Stemonitis virginiensis Rex}

Rare; found in $R$. mangle aerial litter twigs (Table 1).

Although not common, S. virginiensis has broad distribution in the Americas, Asia and Europe, primarily living on decaying wood (Martin and Alexopoulos 1969). In Brazil, it is reported to occur only in the Northeast region, in Pernambuco, Piauí and Sergipe states (Cavalcanti 2014e). It was first reported in mangrove environment by Damasceno et al. (2011), as a rare species in $R$. mangle litter.

\section{Remarks}

Just over half of the species registered in the various substrates were classified as rare, and $30 \%$ were classified as infrequent (Table 1). Contrasting results found by Cavalcanti et al. (2014) for C. erectus, the greatest abundance of myxomycetes in the current study were found on twigs in aerial litter (65\%), followed by live tree trunks $(30 \%)$.

The three species analyzed as substrate occupied different estuarine areas along the study area, and differed in the number of records and myxomycetes species observed in the exploited microhabitats: $A$. nitida inhabits high salinity zones, and only one myxomycetes species was recorded, sporulating in aerial leaf litter; L. racemosa was distributed among intermediate to high salinity zones, with three genera and three species found, sporulating in aerial litter twigs and live trunk bark; $R$. mangle hosted the greatest number of genera (5) and species (7), present in all three microhabitats and more commonly found in intermediate to low salinity areas (Table 1).

Generally, very low values were found for the community coefficients, including those calculated for the three species analyzed as substrate $\left(\mathrm{CC}_{\mathrm{An}} \times \mathrm{Rm}=0.0, \mathrm{CC}_{\mathrm{Lr} \times}\right.$ $\left.\mathrm{An}=0.0, C_{\mathrm{Lr}} \times \mathrm{Rm}=20.0\right)$, and for the microhabitats they occupy $\left(\mathrm{CC}_{\mathrm{Tg}} \times \mathrm{Lf}=0.0 ; \mathrm{CC}_{\mathrm{Bk} \times \mathrm{Lf}}=0,0 ; \mathrm{CC}_{\mathrm{Bk} \times}\right.$ $\mathrm{Tg}=40)$.

In this study, $80 \%$ of the species were present in the aerial litter, two in leaf component and seven in the woody component (Table 1). The taxonomic diversity indices did not differ greatly between microhabitat types (live tree bark $\mathrm{S} / \mathrm{G}=1.0$; aerial leaf litter $\mathrm{S} / \mathrm{G}=1.0$; aerial litter twigs $\mathrm{S} / \mathrm{G}=1.2$ ), nor did they differ between phorophyte species (A. nitida $\mathrm{S} / \mathrm{G}=1.0 ;$ L. racemosa $\mathrm{S} / \mathrm{G}=$ 1.0; $R$. mangle $\mathrm{S} / \mathrm{G}=1.4$ ).

\section{Discussion}

Among the different ecosystems they inhabit, myxomycetes interact with living or dead plants that serve as 
their substrate, as well as with abiotic variables of the environment. Most live on wood debris and leaf litter, feeding on microorganisms that act as decomposers in the ecosystem, such as bacteria and fungi. In mangroves, live or dead plants often come into contact with seawater. Despite these environments have sufficient environmental humidity to allow the development of plasmodium, the salinity level and substrate instability are generally not favorable for sporulation and completion of the life cycle, particularly for K-strategist species (Agra et al. 2010). Although this study did not directly evaluate the influence of estuarine area where phorophytes are found on their microhabitat potential for myxomycetes, the data obtained suggest that the salinity levels of areas commonly inhabited by A. nitida, L. racemosa and $R$. mangle interfere with the composition of myxobiota, and with the abundance and frequency of species among the microhabitats they offer.

The first reports of the presence of myxomycetes in mangroves focused on species that inhabit dead trunks and branches (Kohlmeyer 1969; Novozhilov et al. 2001; Nieves-Rivera and Stephenson 2004). Recent studies show that aerial litter and the bark of living trees above tide level are the preferred microhabitats in such environment (Damasceno et al. 2011; Cavalcanti et al. 2014). This research corroborates that the aerial litter of mangrove trees is commonly inhabited by myxomycetes.

Species found in mangrove are not exclusive to this ecosystem, and uses bark, leaves and twigs as a convenient substratum, irrespective of ground on which the phorophyte occur. Six myxomycete species $(54.5 \%)$ recorded among the three studied phorophytes are cosmopolitan, and some, like A. cinerea, Collaria arcyrionema and $S$. fusca, have previously been discovered in mangroves. Although commonly lignicolous and often found sporulating on fallen trunks and branches on humid forest ground, these and other species occupy different microhabitats than usual in extreme conditions such as mangroves, including the woody component of aerial litter found to be the predominant microhabitat in this study.

\section{Conclusions}

Information on myxomycetes/mangrove associations has greatly increased since myxomycetes were first reported to occur on dead trunks in Hawaiian mangroves by Kohlmeyer (1969). We now know that one or more representative species from all subclasses and orders inhabit this type of environment and an analysis of available publications reveals that about 31 species, belonging to the three subclasses, are recorded on a global scale.

Brazil is the region in which myxomycetes were first reported in mangrove aerial litter and available information is now more abundant for Brazilian mangroves than for other parts of the world.

Mangrove ecosystems are very fragile and needs rational management, appropriate to the characteristics of the sites were they are found (Vannucci 2001). The data presented here complement previous studies conducted in the Rio Formoso mangroves in Pernambuco, and show that estuaries and mangroves are likely to have a larger assemblage of myxomycetes than currently known. Similar studies may contribute to the knowledge and conservation of biodiversity of microorganisms of Brazilian mangroves, and of coastal environments in general.

\section{Acknowledgements}

The authors thank the members of the Myxomycetes Laboratory (LABMIX) of the Universidade Federal de Pernambuco for the help in the fieldwork and in the laboratory. This research was supported by a productivity grant from Conselho Nacional de Desenvolvimento Científico e Tecnológico (CNPq) awarded to L.H. Cavalcanti (proc.305967-2009-6).

\section{Authors' contributions}

LHC conceived of the study, participated in its design and coordination, performed the species identification and ecological analysis and drafted the manuscript. GD conducted fieldwork, collecting myxomycetes specimens and samples of plant material, and participated in the culture and identification of the species. AAAC conducted fieldwork, collecting myxomycetes specimens and samples of plant material, and participated in the herborization and identification of the species. ACCB participated in the identification of the species, performed the ecological analysis and helped to draft the manuscript. All authors read and approved the final manuscript.

\section{Competing interests}

The authors declare that they have no competing interests.

Received: 29 May 2016 Accepted: 3 June 2016

Published online: 06 July 2016

\section{References}

Agra LANN, Lemos DBN, Powell NV, Medrado WT, Cavalcanti LH. Occurrence of Lycogala epidendrum (Myxomycetes) in a mangrove environment in Brazil. Rev Bras Biol. 2010;8:164-8.

Agra L.A.N.N., Bezerra A.C.C. and Cavalcanti L.H. (2015) Myxomycetes from mangroves: species occurring in the state of Maranhão, northeastern Brazil. Brazilian Journal of Biology 75, 222. - 227.

Bezerra ACC, Brito LDB, Guimarães E, Cavalcanti LH. Myxomycetes no manguezal: mixobiota da Reserva Biológica de Santa Isabel, Pacatuba, SE. In: Universidade Federal Rural de Pernambuco, editor. Anais do IX Congresso de Iniciação Científica, UFRPE, Recife. 1999. p. 239-42.

Botelho ERO, Santos MCF, Pontes ACP. Algumas considerações sobre o uso da redinha na captura do caranguejo-uçá, Ucides cordatus (Linnaeus, 1763) no litoral sul de Pernambuco - Brasil. Boletim Técnico Científico do CEPENE. 2000;8:55-71

Cavalcanti L.H. Stemonitales. In: Lista de Espécies da Flora do Brasil. Jardim Botânico do Rio de Janeiro; 2014e. Available at: http://floradobrasil.jbrj.gov.br/ jabot/floradobrasil (accessed 5 Nov 2014).

Cavalcanti LH. Echinosteliales. In: Lista de Espécies da Flora do Brasil. Jardim Botânico do Rio de Janeiro; 2014b. Available at: http://floradobrasil.jbrj.gov. br/jabot/floradobrasil (accessed 5 Nov 2014).

Cavalcanti LH. Liceales. In: Lista de Espécies da Flora do Brasil. Jardim Botânico do Rio de Janeiro; 2014c. Available at: http://floradobrasil.jbrj.gov.br/jabot/ floradobrasil (accessed 5 Nov 2014).

Cavalcanti LH. Physarales. In: Lista de Espécies da Flora do Brasil. Jardim Botânico do Rio de Janeiro; 2014d. Available at: http://floradobrasil.jbrj.gov.br/jabot/ floradobrasil (accessed 5 November 2014).

Cavalcanti LH. Trichiales In Lista de Espécies da Flora do Brasil. Jardim Botânico do Rio de Janeiro; 2014a. Available at: http://floradobrasil.jbrj.gov.br/jabot/ floradobrasil (accessed 5 November 2014). 
Cavalcanti LH, Bezerra ACC, Campos EL. Diversidade da mixobiota de Manguezais. In Mangrove 2000, Sustainable use of estuaries and mangroves: Challenges and prospects; 22-28 may 2000, Recife, Brazil. UFRPE Universidade Federal Rural de Pernambuco, ISME - International Society for Mangrove Ecosystems Brazil. 2000. p. 44-54.

Cavalcanti LH, Damasceno G, Bezerra ACC, Costa AAA. Mangrove myxomycetes: species occurring on Conocarpus erectus L. (Combretaceae). Sydowia. 2014;66:183-90.

Damasceno G, Costa AAA, Passavante JZO, Cavalcanti LH. Stemonaria fuscoides (Stemonitaceae, Myxomycetes): a new record for Brazil. Mycotaxon. 2009;108:205-11.

Damasceno G, Tenório JCG, Cavalcanti LH. Stemonitaceae (Myxomycetes) in Brazilian mangroves. Sydowia. 2011; 63:9-22.

Farr ML. Arcyria cinerea and A. pomiformis revised. Mycologia. 1962;54:516-20.

Farr ML. Flora Neotropica. New York: Organization for Flora Neotropica. New York Botanical Garden; 1976.

Kathiresan K, Bingham BL. Biology of mangrove ecossystems. Adv Mar Biol. 2001; 48:81-251.

Kohlmeyer J. Ecological notes on fungi in mangrove forests. Trans Br Mycol Soc 1969:53:237-50

Krug LA, Leão C, Amaral S. Dinâmica espaço-temporal de manguezais no complexo estuarino de Paranaguá e relação entre decréscimo de áreas de manguezal e dados sócio-econômicos da região urbana do município de Paranaquá - Paraná. São José dos Campos, Instituto Nacional de Pesquisas Espaciais; 2753-2760. 2007. Available at: http://urlib.net/dpi.inpe.br/sbsr@80/ 2006/11.14.20.50 (accessed 5 Sept 2014).

Lado C, Pando F. Myxomycetes I. Ceratiomyxales, Echinosteliales, Liceales, Trichiales. Berlim: Flora Micologica Ibérica, Cramer; 1997.

Leitão SN. A fauna do manguezal. In: Schaeffer-Novelli Y, editor. Manguezal: Ecossistema entre a terra e o mar. São Paulo: Caribbean Ecological Research; 1995. p. 23-8.

Lister A. A monograph of the Mycetozoa. 3ath ed. London: British Museum of Natural History; 1925

Maia LP, Lacerda LD, Monteiro LHU, Souza GM. Estudo das áreas de manguezais do Nordeste do Brasil. Fortaleza, Relatório da Avaliação das áreas de manguezais dos Estados do Piauí, Ceará, Rio Grande do Norte, Paraíba e Pernambuco. 2005. p. 6-54

Martin GW, Alexopoulos CJ. The Myxomycetes. lowa: University of lowa Press; 1969.

Nieves-Rivera AM, Stephenson SL. The occurrence of Stemonitis splendens (Myxomycota: Stemonitales) on Rhizophora mangle. Caribb J Sci. 2004; 40:273-6.

Novozhilov YK, Schnittler M, Zemlianskaia IV, Fefelov KA. Biodiversity of plasmodial slime moulds (Myxogastria): measurement and interpretation. Protistology. 2000;1:161-78.

Novozhilov YK, Schnittler M, Rollins AW, Stephenson SL. Myxomycetes from different forest types in Puerto Rico. Mycotaxon. 2001;77:285-99.

Novozhilov YK, Zemlyanskaya IV, Schnittler M, Stephenson SL. Myxomycete diversity and ecology in the arid regions of the Lower Volga River Basin (Russia). Fungal Divers. 2006:23:193-241.

Poulain M, Meyer M, Bozonnet J. Les Myxomycétes. Sévrier: Fédération Mycologique et Botanique Dauphiné-Savoie; 2011.

Schaeffer-Novelli Y. Manguezal:Ecossistema entre a terra e o mar. São Paulo: Carabbean Ecological Research; 1995.

Schnittler M, Stephenson SL. Myxomycete biodiversity in four different forest types in Costa Rica. Mycologia. 2000;92:626-37.

Schuler CAB, Andrade VC, Santos DS. O manguezal: Composição e estrutura. In: Barros HMB, Macedo SJ, Leça EE, Lima T, editors. Gerenciamento participativo de estuários e manguezais. Recife: Editora Universitária da UFPE; 2000. p. 27-38.

Sridhar KR. Mangrove fungi in Índia. Curr Sci. 2004;86:1586-7.

Thiers B. Index Herbariorum: a global directory of public herbaria and associated staff. NewYork Botanical Garden's Virtual Herbarium; 2014. Available at:http:// sweetgum.nybg.org/ih (accessed 5 Nov 2014).

Trierveiler-Pereira L, Baltazar JM, Loguercio-Leite C. Santa Catarina Island mangroves - First report of Myxomycetes on Avicennia schaueriana. Mycotaxon. 2008;103:145-52.

Vannucci M. What is so special about mangroves? Braz J Biol. 2001;61:599-603.

\section{Submit your next manuscript to BioMed Central and we will help you at every step:}

- We accept pre-submission inquiries

- Our selector tool helps you to find the most relevant journal

- We provide round the clock customer support

- Convenient online submission

- Thorough peer review

- Inclusion in PubMed and all major indexing services

- Maximum visibility for your research

Submit your manuscript at www.biomedcentral.com/submit

) Biomed Central 